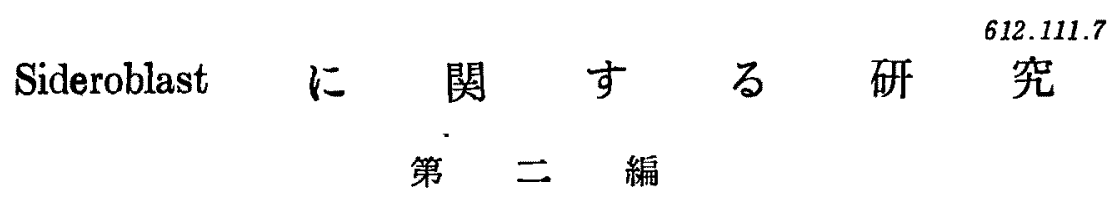

骨噵 機能（実験的賓 血）と Sideroblast

（本諭文要旨は第 17 回日本血液学会総会飞於いて発表した）

盛山大学医学部平木内科（主任：平木 潔解授）

助手木 村 郁 郎

[昭和 32 年 7 月 4 日受稿]

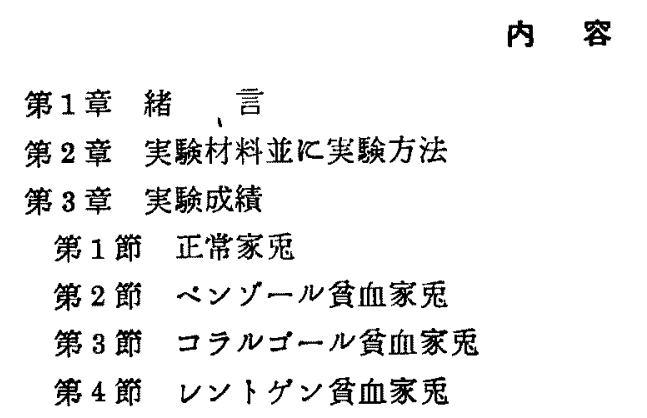

\section{第1章腥言}

前編飞於いて私は諸種血液疾患患者につき Sideroblast $の$ 検索を行い，血液疾患の鑑別に 奇与する所実に大なる事を認めた。 而してこ の Sideroblast を中心として諸種血液疾患の 鉄代謝に関する再検討を行い，赤芽球鉄が鉄 の中間段階の代謝物質として鉄の利用過程飞 於いて重要な位置を占め，生体に於ける代謝 情況を知る上に血清鉄同様否それ以上に価值 を有している事を識つた。

茲に鉄の代謝を経通的に概観すれば，鉄が 腸管に於いて吸收されてょり骨髄内赤芽球で の血色素合成に至る迄には幾つかの複雑な段 階を経る，即ち腸粘膜に於いては吸收機棈に 関し Granick ${ }^{75) 76)}$ の提唱せる mucosal block なる説があり，吸收後血清中に入ると Transferrin と結合して㼨器へと輸送され，又網内 系等に於いては Ferritin, Hemosiderin 等の 鉄蛋白体として賍蔵され，再び動員される事 等が明か飞されて括り，斯かる段階を経て骨
第 5 節 急性瀉血貧血家鬼

第 6 節 慢性瀉血貧血家兔

第 7 節 フェニールヒドラシン貧血家鬼

第 8 節 サポニン貝血家鬼

第 4 章 総括並に考按

第 5 章 結 諭

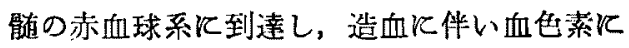
利用されて行く訳である。等非へミン鉄の 中で最終的位置飞存在するるのが赤第球鉄で あり，血清鉄亚に骨鹃の造赤血球機能と深く 関係している事は私の成績より見てる明白で ある。即ち血液諸疾患の検索から得た結果は この赤芽球鉄が血清中より送られた鉄の造血 飞伴う血色素合成飞至る途上飞存在し，この 前後より影響されるという事であり，而して 造血障䅞時にこの增加を認め, 又高血清鉄值 に際し一定度以上の高染に認められるる，高

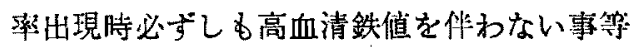
は血清鉄 $\rightarrow$ 赤牙球鉄 $\rightarrow$ 血色素と代謝の進行が 力问付けられ，決して逆行しない事を示すも のとして興味がある、換言すればこの赤芽球 鉄は単なる貯蔵形式のるのでなく，利用とい 5 代謝の主流化乘つて存在し，かつ移動する ものであり，従つて Fe-transferrin と本䝷的 には同一の役割を有し，利用に対する貯藏に 非ずして利用とい5方角付けられた代謝経路 に於ける貯㓫なる表覞が適切である5。 
私は斯かる現象に対して更に之を確認する ため，実騟動物を用いてその究明の步を進め

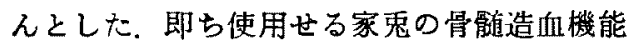
状熊を種々変化させる事によりり Sideroblast の推移を血清鉄と共に観察し，骨邻機能の変 動が如何に赤芽球鉄に影響を及ぼすかという 問題を主体として，人体汸於いて十分飞究明 し得なかつた諸㮔の事象に対して㭘討を重ね, 鉄代謝に於ける Sideroblast 万至赤第球鉄の 取る位圈亚に演ずる役别につき更に一段の解 明を与えるへく追求を試みた，而して又同時

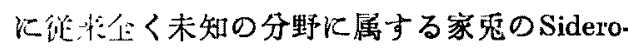
blast に対し之が全貌を明かにすへく検䋈に 務めた。

\section{第 2 章 実䀦材料並に実験方法}

実騟材料

1）正常家鬼：体重 $2 \mathrm{~kg}$ 前後の白色雄性芜 鬼について血液像の正常範囲のすのを選び, 実駼対照として使用し，更に下記の諸操作を 施して同一個体に於ける連続観察を実施し t.

2）ベンソール算血家鬼：ベンゾールを件 重 pro kg 0.3 cc 宛 30 回背部皮下飞每回場所 を変えて速䋨注射し盆血を招来せしめた。

3）コラルゴール盆监家桹：1\%コラルゴ 一N生理的值塩水浴液を $60^{\circ} \mathrm{C}$ にて 1 時間減 菌し，耳静脈より体重 pro $\mathrm{kg} 2 \mathrm{cc}$ 㝖 15 回锌 日連絖注射し實血を招来せしめた。な柱射 液は每週新たに調製した。

4）レントグン筫血家鬼： $\mathrm{X}$ 線発生装置は 東芝 K. X.C. 17 型を使用し，照射条件は管

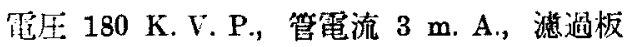
$0.5 \mathrm{mmCu}+1.0 \mathrm{mmAl}$, 照射距離 $40 \mathrm{~cm}$, 分 レントゲン 15 として全身照射を行い，而し て之により家鬼の全身状態を観察しつつ1日 300 r. Kて 8 日間に 1500 r. 照射せる急性の 場合，及び1日 100 r. そて45日間に 3500 r. 照射せる慢性の埸合とを笑施し，盆血を招来 せしめた。

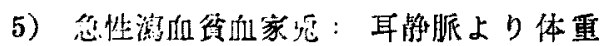

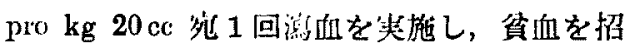

来せしめ 4 日後に寒験に供した。

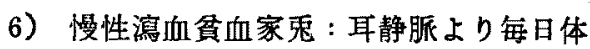
重 pro $\mathrm{kg} 5 \mathrm{cc}$ 宛 15 回連続瀉血を実施し, 後 5 日間放置し䨘血を招来せしめた。

7）フェニールヒドラシン垻血家鬼：1\% 塩酸フェニールヒドラシンン水溶液を体重 pro $\mathrm{kg} 3 \mathrm{cc}$ 宛 1 回背部皮下飞注射し，貧血を招 米せしめ 5 日後に実験に供した。

8）サポニン負血家鬼：0.2\%6サポニン水 溶液を作重 pro kg $0.5 \mathrm{cc}$ 宛より每日 pro kg $0.1 \mathrm{cc}$ づ濑增与る事により体重 pro kg $2 \mathrm{cc}$ 㱜迄増量し，20回背部皮下に毎回場所を变え て連続注射し，賓血を招来せしめた。

実験方法

家鬼の同一個体を用いて貧血惹起操作前の 正常状態及び貧血状態更に一部は回復状態に 於ける推移を連続的に観察した。

Sideroblast の検出には大腿骨骨髄を使用し たが，塗㧣標本の作製飞当つては次の 2 通り の方法をとつた。な大腿骨骨敷の左右並に 各部位による差異は認められなかつた。

1）骨髄吸引法：採取後な持生存の必要あ る場合飞笑施せるるので，家鬼を腹卧位涸 定し大腿骨直上の皮度並飞筇膜を約 $2 \mathrm{~cm}$ 切闢 し，筇肉間を骨に達し，骨穿孔器により頭倒 より䄪 $1 / 3$ の部位飞小孔を穿ち，予め短かく 調整せる注射針化て大吸引力を用いて骨噵の 忣引を行つた。 な打吸引量は侵紫を少くする ため可及的少量とし，塗抹標本 $2 \sim 3$ 枚作製 乙得る程度に止め，又実施に当つては大腿骨。 を左右交互に選定した。

2）骨傕押捺法：以後の観察を中止する場 合に笨施せるもので，家兔を頊動脈切断によ り瀉血死せしめ, 直前の吸引側と反対の大腿 骨骨颌に於いてその頭側より1/3を中心とし た部位を取出し，生理的食塩水の極く少量を 加えて骨髄を圧笠し，細胞を遊出せしめて之 の塗枺を行つた。

以上の如くして作製せる骨䯣塗抹標本につ いて前編と同一の方法により固定並飞染色を 行い, 然る後鏡娭し, Sideroblast を前編の如 くI， II， III 型飞分類し，I 型は更飞 I a, 
I b 型に細分類した．又同時に゙ギムザ染色に よる標本とも併せ観察を行つた。

而して血清鉄量飞関しては前編と同様の方 法従い o-phenanthroline Kよる比色定量 を実施し，又末梢血液についても同様血色素 量（ザーリ一氏法），赤血球数及び網赤血球 数の算定を行つた。 なお Sideroblast の模出 並に血清鉄量の測定に関しては前編に詳述せ るため，此処では省略する。

\section{第3章 実臨 成 経}

\section{第 1 節 正常家鬼（第 1 㤗）}

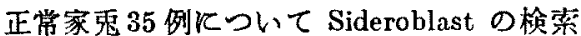
を行つた所，7２2％の出現を見，平均 14.4 名なる值を示し，硉康人の Sideroblast より も低率であり，又その勘摇笔囲子僅かで可成 ク一定した值を示した，而して趾康人の場合 々同栐沃決して之の存在しない例に浩遇し なかつた。

各型の分類化於いてはI 型が大多数を占め， II型は極く少数例に出現を見る程度でその数 る少く，四型は全例飞認められなかつた，更 飞I型飞於いてはＩａ型が压倒的多数であり， I b 型は少数で認められない例もあつた，即 占正常家兔で前編の血液疾患思者中铁欠之 型の上界附䜣と同滕の值をとり，出現摔も 10 〜20\%の間が殆んどを占めているという事が 出来了。

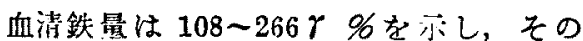
大多数かi $200 r$ 前後の值をとり，而して Sideroblasi と血清鉄量とは多少共閏聯性を有 する如く見受けられるが，確然たる梾相を示 していない，又鉄顆粒の性状は鉄欠乏性疾渑 飞認められる如き小かつ淡染せる場合に浪任 一致せる様相を呈した。

第 1 表に揭载せるるのは総へて次節以後に 示す貧血操作前の值であるが，分り易くする ため重複を顧みず一括表示する事とした，

第 2 節 ベンソール盆血家鬼（第 2 表， 第 1 図)

本貧血を招来せしめた 5 例について経過的

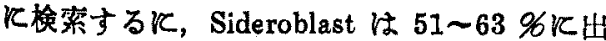

第1 表 正常 家 鬼

\begin{tabular}{|c|c|c|c|c|c|c|c|c|c|c|}
\hline \multirow{2}{*}{$\begin{array}{c}\text { 家 } \\
\text { 兔 } \\
\text { 番 } \\
\text { 号 } \\
\text { (No.) }\end{array}$} & \multirow{2}{*}{$\begin{array}{c}\text { 体 } \\
\\
\text { 重 } \\
(\mathrm{kg})\end{array}$} & \multirow{2}{*}{$\begin{array}{c}\text { 血 } \\
\text { 色 } \\
\text { 菜 } \\
\text { 量 } \\
(\mathscr{6})\end{array}$} & \multirow{2}{*}{$\begin{array}{c}\text { 赤 } \\
\text { 血 } \\
\text { 球 } \\
\text { 数 } \\
\left(y^{\prime}\right)\end{array}$} & \multirow{2}{*}{$\begin{array}{c}\text { 網 } \\
\text { 赤 } \\
\text { 血 } \\
\text { 球 } \\
\text { 数 } \\
\left(\begin{array}{c}0 \\
\%\end{array}\right)\end{array}$} & \multicolumn{5}{|c|}{$\begin{array}{l}\text { Sideroblast } \\
(\mathscr{C})\end{array}$} & \multirow{2}{*}{$\begin{array}{c}\text { 血 } \\
\text { 清 } \\
\text { 鉄 } \\
\text { 量 } \\
(7 \%)\end{array}$} \\
\hline & & & & & $\begin{array}{l}I \\
\mathbf{a} \\
\text { 型 }\end{array}$ & $\left|\begin{array}{c}I \\
b \\
\text { 型 }\end{array}\right|$ & & $\begin{array}{l}\text { III } \\
\text { 型 }\end{array}$ & $\begin{array}{l}\text { 総 } \\
\text { 計 }\end{array}$ & \\
\hline 1 & 2.0 & 85 & 665 & 17 & 8 & & & & 8 & 160 \\
\hline 2 & 1.9 & 81 & 492 & 25 & 12 & 3 & 1 & & 16 & 206 \\
\hline 3 & 2.0 & 80 & 493 & 17 & 16 & 2 & & & 18 & 108 \\
\hline 4 & 2.1 & 84 & 480 & 14 & 6 & 1 & & & 7 & 187 \\
\hline 5 & 1.9 & 85 & 534 & 25 & 7 & 3 & 1 & & 11 & 170 \\
\hline 6 & 2.0 & 78 & 537 & 10 & 10 & 1 & & & 11 & 182 \\
\hline 7 & 2.1 & 80 & 587 & 12 & 12 & 2 & & & 14 & 192 \\
\hline 8 & 2.25 & 79 & 525 & 10 & 11 & 3 & & & 14 & 220 \\
\hline 9 & 2.35 & 83 & 535 & 18 & 12 & 3 & & & 15 & 158 \\
\hline 10 & 2.05 & 85 & 448 & 25 & 12 & & & & 12 & 188 \\
\hline 11 & 2.8 & 83 & 504 & 24 & 13 & 3 & 3 & & 19 & 204 \\
\hline 12 & 2.6 & 85 & 575 & 13 & 12 & & & & 12 & 182 \\
\hline 13 & 2.9 & 87 & 510 & 13 & 9 & 1 & & & 10 & 198 \\
\hline 14 & 3.05 & 85 & 555 & 12 & 6 & 2 & 1 & & 9 & 176 \\
\hline 15 & 2.0 & 84 & 431 & 27 & 8 & 1 & & & 9 & 266 \\
\hline 16 & 1.8 & 80 & 460 & 18 & 8 & & & & 8 & 164 \\
\hline 17 & 1.58 & 85 & 462 & 10 & 17 & & & & 17 & 154 \\
\hline 18 & 1.54 & 83 & 422 & 28 & 16 & 4 & & & 20 & 152 \\
\hline 19 & 1.3 & 82 & 494 & 14 & 13 & 1 & 1 & & 15 & 184 \\
\hline 20 & 2.25 & 75 & 477 & 24 & 13 & 6 & & & 19 & 180 \\
\hline 21 & 2.25 & 77 & 545 & 21 & 18 & 1 & 3 & & 22 & 160 \\
\hline 22 & 2.05 & 81 & 569 & 12 & 11 & 8 & & & 19 & 152 \\
\hline 23 & 2.9 & 78 & 459 & 12 & 20 & & & & 20 & 242 \\
\hline 24 & 2.2 & 80 & 650 & 15 & 20 & & & & 20 & 266 \\
\hline 25 & 2.1 & 72 & 500 & 15 & 16 & & & & 16 & 216 \\
\hline 26 & 2.1 & 82 & 448 & 10 & 10 & 2 & & & 12 & 176 \\
\hline 27 & 2.3 & 77 & 459 & 23 & 14 & 2 & & & 16 & 188 \\
\hline 28 & 1.92 & 79 & 516 & 17 & 11 & 1 & & & 12 & 176 \\
\hline 29 & 1.88 & 80 & 477 & 12 & 14 & 3 & & & 17 & 222 \\
\hline 30 & 2.42 & 80 & 483 & 10 & 10 & 1 & & & 11 & 208 \\
\hline 31 & 1.9 & 78 & 484 & 14 & 11 & 2 & & & 13 & 192 \\
\hline 32 & 2.1 & 82 & 470 & 24 & 13 & 6 & 3 & & 22 & 242 \\
\hline 33 & 1.9 & 87 & 445 & 22 & 10 & 1 & & & 11 & 164 \\
\hline 34 & 1.9 & 74 & 457 & 9 & 12 & & & & 12 & 144 \\
\hline 35 & 2.1 & 83 & 403 & 24 & 15 & 1 & & & 16 & 162 \\
\hline
\end{tabular}

現し，何れも正常状態から50\%前後の著明な 增加を認めた。而して各型の增加す著明で 殊飞 I b 型及びII型は全例にその出現を見， 中 1 例の No. 1 家鬼ではIII型の出現をる認め た.

血清鉄䭪は著明ではないにしても殆んどの 
符 2 表 ベンゾール䆩血

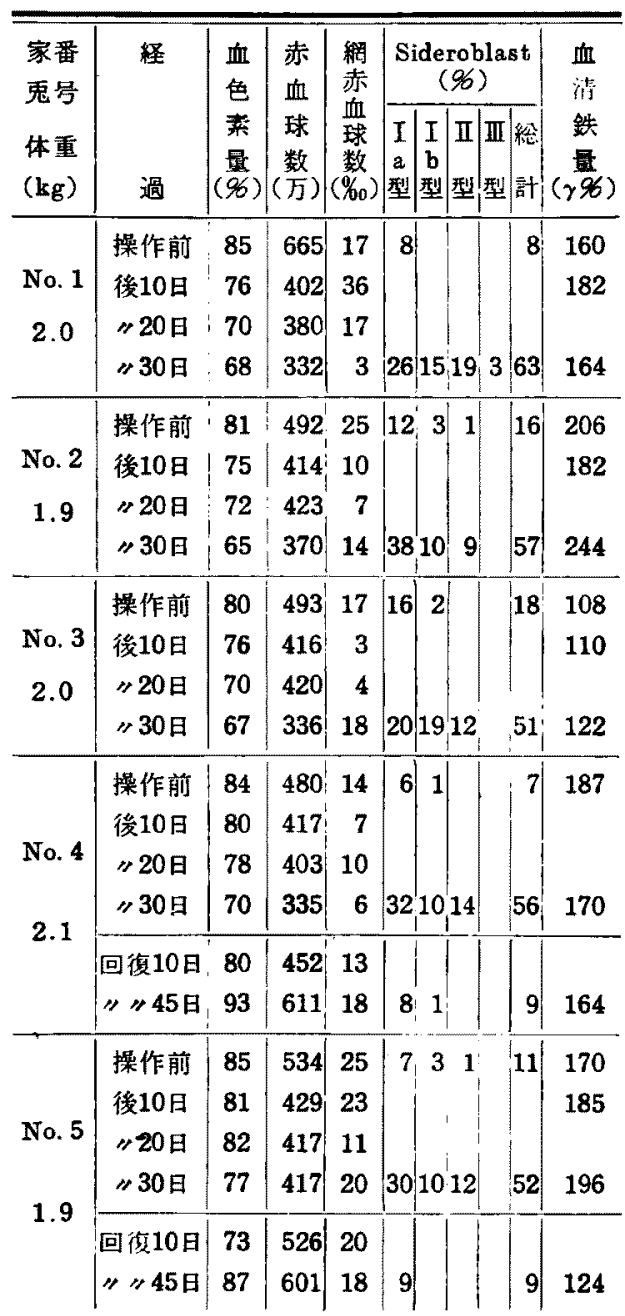

第 1 図 ベンソール貧扣の Sideroblast

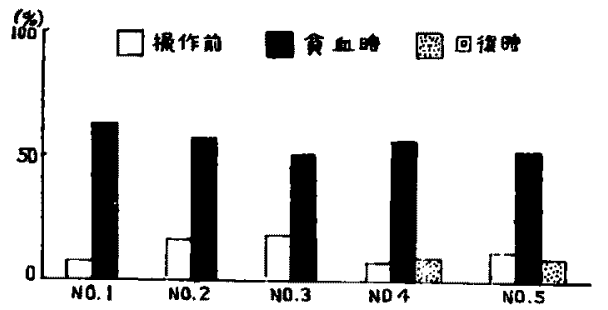

例に於いて增加傾向を示し，No. 4 家鬼の 1 例飞軽度減少を認めたのみであつた，又鉄顆 粒は正常状態に比して大かつ濃染する傾向が 強く可成り明暸に認められた。

更飞No.4，No. 5 の 2 例では坌血極期以後 45日を経渦し, 血液像の完全に回復した状態
飞於いて Sideroblast の検出を再度試みた所。 2 例共再び減少し全く正常值飞復帰している のを確認した．而してこの際血清鉄量る同様 そ減少傾向を示し，鉄顆粒る再び元の小かつ 淡染せる状態をとる事が観繁された。

以上本筫血操作於いて Sideroblast と血 清鉄量の変動は注ほ平行的飞推移するが, Sideroblast の変動は血清鉄の乞れに比し遙か に高度である.

第3節 コラルゴール貧血家鬼

（第 3 表，第 2 図）

本貧血操作を行つた 5 例について検索する

第 3 表 コラルゴール貧血

\begin{tabular}{|c|c|c|c|c|c|c|c|c|c|}
\hline \multirow{2}{*}{$\begin{array}{l}\text { 家番 } \\
\text { 兔号 } \\
\text { 体重 } \\
\text { (kg) }\end{array}$} & \multirow{2}{*}{$\begin{array}{l}\text { 経 } \\
\\
\text { 過 }\end{array}$} & \multirow{2}{*}{$\begin{array}{l}\text { 血 } \\
\text { 色 } \\
\text { 菜 } \\
\text { 量 } \\
(\mathscr{6})\end{array}$} & \multirow{2}{*}{$\begin{array}{l}\text { 赤 } \\
\text { 血 } \\
\text { 球 } \\
\text { 数 } \\
\text { (万) }\end{array}$} & \multirow{2}{*}{$\begin{array}{c}\text { 網 } \\
\text { 赤 } \\
\text { 血 } \\
\text { 球 } \\
\text { 数 } \\
(\% 0)\end{array}$} & \multicolumn{4}{|c|}{$\begin{array}{c}\text { Sideroblast } \\
(\mathscr{6})\end{array}$} & \multirow{2}{*}{\begin{tabular}{|c} 
血 \\
清 \\
鉄 \\
最 \\
$(\gamma \%)$
\end{tabular}} \\
\hline & & & & & & \begin{tabular}{l|l}
$\mathrm{I}$ & $\mathrm{II}$ \\
$\mathrm{b}$ & $\mathrm{II}$ \\
型| & 型
\end{tabular} & & 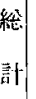 & \\
\hline \multirow{3}{*}{$\begin{array}{c}\text { No. } 6 \\
2.0\end{array}$} & 操作前 & 78 & 537 & 10 & 10 & 1 & & 11 & 182 \\
\hline & 後 7 日 & 64 & 465 & 25 & & & & & 160 \\
\hline & "15日 & 57 & 324 & 3 & & 1421 & & 52 & 214 \\
\hline \multirow{3}{*}{$\begin{array}{c}\text { No. } 7 \\
2.1\end{array}$} & 操作前 & 80 & 587 & 12 & 12 & 2 & & 14 & 192 \\
\hline & 後 7 日 & 72 & 411 & 10 & & & & & 147 \\
\hline & "15日 & 51 & 316 & 4 & & $22: 20$ & & 70 & 183 \\
\hline \multirow{3}{*}{$\begin{array}{l}\text { No. } 8 \\
2.25\end{array}$} & 操作前 & 79 & 525 & 10 & 11 & 3 & & 14 & 220 \\
\hline & 後 7 日 & 71 & 459 & 11 & & & & & 140 \\
\hline & »15日 & 51 & 385 & 16 & & 1627 & & 63 & 192 \\
\hline \multirow{3}{*}{$\begin{array}{l}\text { No. } 9 \\
2.35\end{array}$} & 操作前 & 83 & 535 & 18 & 12 & 3 & & 15 & 158 \\
\hline & 後 7 日 & 62 & 395 & 14 & & & & & 121 \\
\hline & "15日 & 50 & 302 & 41 & & $14 \mid 21$ & & 67 & 154 \\
\hline \multirow{4}{*}{$\begin{array}{l}\text { No. } 10 \\
2.05\end{array}$} & 操作前 & 85 & 448 & 25 & 12 & & & 12 & 188 \\
\hline & 後 7 日 & 55 & 409 & 8 & & & & & \\
\hline & " 15 日 & 20 & 124 & 2 & & & & & \\
\hline & 放置 7 日 & 16 & 83 & 0 & & 10,40 & & 80 & \\
\hline
\end{tabular}

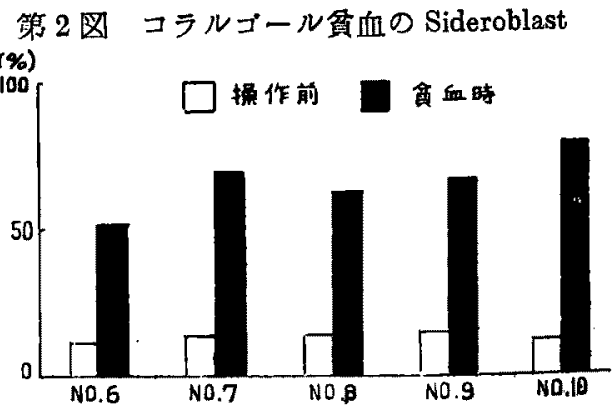


K, Sideroblstは 52〜80\%の出現を示し, 全 例共正常状態飞比して著明な増加を認めた事 は前節のヘンンソール筫血を上备るすのがある， 又徒つて各型の增加す著しく，I b 型及びII 型の増加は印象的であり，就中 No. 10家鬼保 於いては貧血操作中止後放置せる化す拘わら ず回復の兆更になく，漸次貧血高度となり， 再生不良生貧血同様の所睍を呈し，血色素量 並に赤血球数の減少甚しく，II 型の增加は特 に著しく, 同時に又相当数のIII型の出現をる 証明し，前編飞述へた再生不良性貧血型と同 一の像を呈し, 全冒血操作例中最高値を示し ז.

之に対し血清鉄量は増减不定なるも之等は 極く僅かの变動であり, 殆んど現状維持の状 熊を示す如く見受けられた，即ち本資血では Sideroblast と血清鉄量との間に何等認むべき 相関なく, Sideroblastの一方的著增のみが存 在した. 又鉄顆粒は大かつ濃染し極めて明瞭

第 4 表 レントゲン筫血

\begin{tabular}{|c|c|c|c|c|c|c|c|c|c|c|}
\hline \multirow{2}{*}{\multicolumn{2}{|c|}{$\mid \begin{array}{l}\text { 家番 } \\
\text { 鬼号 } \\
\text { 体重 } \\
(\mathrm{kg})\end{array}$}} & \multirow{2}{*}{$\begin{array}{c}\text { 経 } \\
\\
\text { 過 }\end{array}$} & \multirow{2}{*}{$\begin{array}{l}\text { 血 } \\
\text { 色 } \\
\text { 素 } \\
\text { 量 } \\
(\mathscr{6})\end{array}$} & \multirow{2}{*}{$\begin{array}{c}\text { 赤 } \\
\text { 血 } \\
\text { 球 } \\
\text { 数 } \\
\text { (万) }\end{array}$} & \multirow{2}{*}{$\begin{array}{l}\text { 網 } \\
\text { 赤 } \\
\text { 血 } \\
\text { 球 } \\
\text { 数 } \\
(\%, 0)\end{array}$} & \multicolumn{4}{|c|}{$\begin{array}{c}\text { Sideroblast } \\
(\%)\end{array}$} & \multirow{2}{*}{$\begin{array}{c}\text { 血 } \\
\text { 清 } \\
\text { 鉄 } \\
\text { 量 } \\
(\gamma \%)\end{array}$} \\
\hline & & & & & & $\left|\begin{array}{c}I \\
\mathbf{a} \\
\text { 型 }\end{array}\right|$ & \begin{tabular}{l|l} 
I & I \\
型型 &
\end{tabular} & III & II 総 & \\
\hline & $\begin{array}{c}\text { No. } 11 \\
2.8\end{array}$ & $\begin{array}{l}\text { 操作前 } \\
\text { 後20日 } \\
\text { "45日 }\end{array}$ & $\begin{array}{l}83 \\
72 \\
65\end{array}$ & $\begin{array}{l}504 \\
451 \\
370\end{array}$ & $\begin{array}{r}24 \\
3 \\
5\end{array}$ & 13 & 3 & 3 & 33 & $\begin{array}{l}204 \\
217 \\
152\end{array}$ \\
\hline & $\begin{array}{c}\text { No. } 12 \\
2.6\end{array}$ & $\begin{array}{l}\text { 操作前 } \\
\text { 後20日 } \\
\text { "45日 }\end{array}$ & $\begin{array}{l}85 \\
83 \\
70\end{array}$ & $\begin{array}{l}575 \\
542 \\
392\end{array}$ & $\begin{array}{l}13 \\
12 \\
25\end{array}$ & 12 & 7 & 4 & 26 & $\begin{array}{l}182 \\
180 \\
158\end{array}$ \\
\hline & $\begin{array}{c}\text { No. } 13 \\
2.9\end{array}$ & $\left|\begin{array}{|}\text { 操作前 } \\
\text { 後20日 } \\
\mid 45 \text { 日 }\end{array}\right|$ & $\begin{array}{l}87 \\
79 \\
61\end{array}$ & $\begin{array}{l}510 \\
472 \\
396\end{array}$ & $\begin{array}{r}13 \\
2 \\
38\end{array}$ & 28 & 1 & 8 & 40 & $\begin{array}{l}198 \\
230 \\
170\end{array}$ \\
\hline & $\begin{array}{c}\text { No. } 14 \\
3.05\end{array}$ & $\begin{array}{l}\text { 操作前 } \\
\text { 後20日 } \\
\text { " 45日 }\end{array}$ & $\begin{array}{l}85 \\
70 \\
59\end{array}$ & $\begin{array}{l}555 \\
481 \\
350\end{array}$ & $\begin{array}{r}12 \\
6 \\
6\end{array}$ & 19 & 5 & 2 & 26 & $\begin{array}{c}176 \\
189 \\
194\end{array}$ \\
\hline 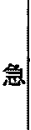 & $\begin{array}{c}\text { No. } 15 \\
2.0\end{array}$ & $\mid \begin{array}{ll}\text { 操作前 } \\
\text { 後 } 4 \text { 日 } \\
\Rightarrow 8 \text { 日 }\end{array}$ & $\begin{array}{l}84 \\
75 \\
70\end{array}$ & $\begin{array}{l}431 \\
414 \\
361\end{array}$ & $\begin{array}{r}27 \\
4 \\
3\end{array}$ & & 101 & 7 & 55 & 232 \\
\hline & $\begin{array}{c}\text { No. } 16 \\
1.8\end{array}$ & $\mid \begin{array}{l}\text { 操作前 } \\
\text { 後 } 4 \text { 日 } \\
\text { " } 8 \text { 日 }\end{array}$ & $\begin{array}{l}80 \\
69 \\
68\end{array}$ & $\begin{array}{l}460 ! \\
383 \\
354\end{array}$ & $\begin{array}{r}18 \\
11 \\
9\end{array}$ & 8 & & & 8 & 170 \\
\hline
\end{tabular}

飞出現する傾向を有した。

第 4 節 レントグン貧血家兔

（第 4 表，第 3 図）

レントゲン照射による慢性筫血 4 例並に急 性盆血 2 例について検索を行つたが, Sideroblastは26〜55 \%6出現し，而して全例共に 正常状態からの増加を認めた，内慢性型では 中等度の增加を示し，又急性型では 1 例は慢 性型同様中等度の増加を示したが，他の 1 例 の No. 15 家兔では前 2 節の賽血と同様に著明 なる増加を認めた，又全例を通じてIb 型及 びII型の出現が見られたが，型は出現を認 めなかつた。

血清鉄量に関しては総体的に多少共減少す る傾向が見受けられた，又鉄顆粒の性状も正 常状態に比䡥して明瞭化する傾向を有した.

而して之等レントグン照射による家鬼骨殖 は膠様を示するの多く，細胞成分の減少が認 められる傾向にめつた.

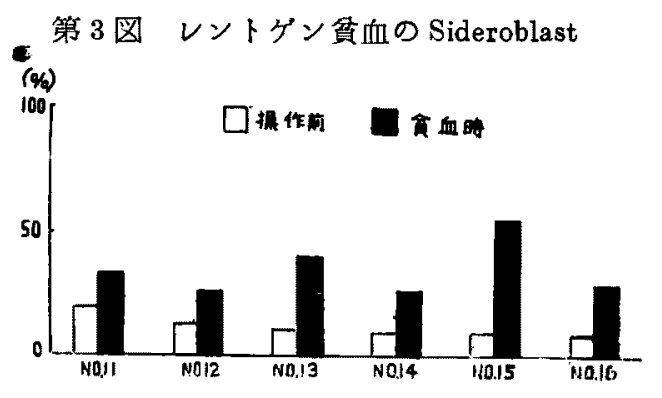

第 5 節 急性演血負血家鬼（第 5 表， ，第 4 図）

本貧血操作を行つた 4 例について網赤血球

第 4 図急性瀉血貧血の Sideroblast

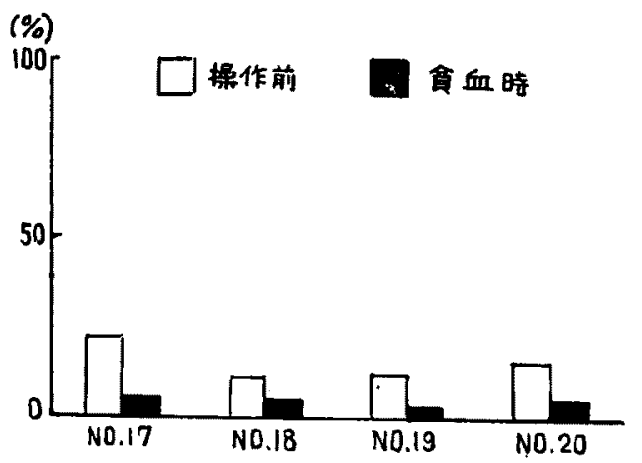


第 5 表 急性演血筫血

\begin{tabular}{|c|c|c|c|c|c|c|c|c|c|}
\hline \multirow{2}{*}{$\begin{array}{c}\text { 家番 } \\
\text { 鬼号 } \\
\text { 体重 } \\
(\mathbf{k g})\end{array}$} & \multirow{2}{*}{$\begin{array}{l}\text { 経 } \\
\text { 過 }\end{array}$} & \multirow{2}{*}{$\begin{array}{l}\text { 血 } \\
\text { 色 } \\
\text { 素 } \\
\text { 量 } \\
\left(\frac{6}{6}\right)\end{array}$} & \multirow{2}{*}{$\begin{array}{c}\text { 赤 } \\
\text { 血 } \\
\text { 球 } \\
\text { 数 } \\
(\text { 号 }\end{array}$} & \multirow{2}{*}{$\begin{array}{l}\text { 勫 } \\
\text { 赤 } \\
\text { 血 } \\
\text { 球 } \\
\text { 数 } \\
(\% 00)\end{array}$} & \multicolumn{4}{|c|}{ 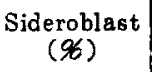 } & \multirow{2}{*}{$\begin{array}{c}\text { 血 } \\
\text { 清 } \\
\text { 鉄 } \\
\text { 量 } \\
(\gamma 9)\end{array}$} \\
\hline & & & & & \begin{tabular}{|c|c}
$I$ & $\mathrm{I}$ \\
$\mathbf{a}$ & $\mathbf{b}$ \\
型 & 型 \\
\end{tabular} & b & & $\left\{\begin{array}{l}\text { 総 } \\
\text { 計 }\end{array}\right.$ & \\
\hline $\begin{array}{c}\text { No. } 17 \\
1.58\end{array}$ & $\begin{array}{l}\text { 操作前 } \\
\text { 後 } 2 \text { 日 } \\
\text { " } 4 \text { 日 }\end{array}$ & $\begin{array}{l}82 \\
64 \\
66\end{array}$ & $\begin{array}{l}470 \\
310 \\
397\end{array}$ & $\begin{array}{l}24 \\
91 \\
52\end{array}$ & 136 & 33 & & 22 & 242 \\
\hline $\begin{array}{c}\text { No. } 18 \\
1.54\end{array}$ & $\begin{array}{l}\text { 操作前 } \\
\text { 後 } 2 \text { 日 } \\
\text { " } 4 \text { 日 }\end{array}$ & $\begin{array}{l}87 \\
61 \\
73\end{array}$ & $\begin{array}{l}445 \\
312 \\
385\end{array}$ & $\begin{array}{r}22 \\
124 \\
125\end{array}$ & ${ }_{4}^{10,1} 1$ & & & 11 & 164 \\
\hline $\begin{array}{c}\text { No. } 19 \\
1.3\end{array}$ & $\begin{array}{l}\text { 操作前 } \\
\text { 後 } 2 \text { 日 } \\
\text { " } 4 \text { 日 }\end{array}$ & $\begin{array}{l}74 \\
56 \\
59\end{array}$ & $\begin{array}{l}457 \\
321 \\
350\end{array}$ & $\begin{array}{r}9 \\
115 \\
76\end{array}$ & 12 & & & 12 & 144 \\
\hline $\begin{array}{c}\text { No. } 20 \\
2.25\end{array}$ & $\begin{array}{l}\text { 操作前 } \\
\text { 後 } 2 \text { 日 } \\
\text { " } 4 \text { 日 }\end{array}$ & $\begin{array}{l}83 \\
57 \\
68\end{array}$ & $\begin{array}{l}403 \\
335 \\
358\end{array}$ & $\begin{array}{r}24 \\
206 \\
115\end{array}$ & 5 & & & 16 & 140 \\
\hline
\end{tabular}

増多を来した骨蹎再生機能比盛なる時期を選 び検染を行つた。

Sideroblast 注全例共飞減少佰を示し $3 \sim 5$ \%6証明され，各型別に見るとI b 型以下は 完全飞消失し，Ia 型も減少が著明であつた が消生する例には会涯しなかつた。

血清鉄量は全例其儿減少し，殊飞激減する 傾向が強かつた．鉄顆粒については小かつ淡 染する傾向を認めた。

第 6 節 慢性瀉血畕血家鬼（第 6 法， 第 5 図)

朴盆血 4 例飞ついて頻回滨血により著明な 貣血を来する，な招網赤血球增多を認める時 期飞㭘絷を行つた。

Sideroblast の減少は高度で 0〜 1\%飞酒明 され，念性時の減少を凌唯した。 内 2 例の No. 22 及び No. 24 家鬼に於いては完企に消 失する像を呈し，又出現例に於いてす196 いら殆んど消少同然の值を示した事は注目に 值する，各型別に見れば出現はIa 型のみで あり，勿論 $\mathrm{Ib}$ 型以下は全例共飞消失を見 た.

血清鉄量飞ついても前慨同様高度の減少を 認めた。 又釗顆精も同梯火小かつ淡染した。
第 6 表 慢性鹪血貧血

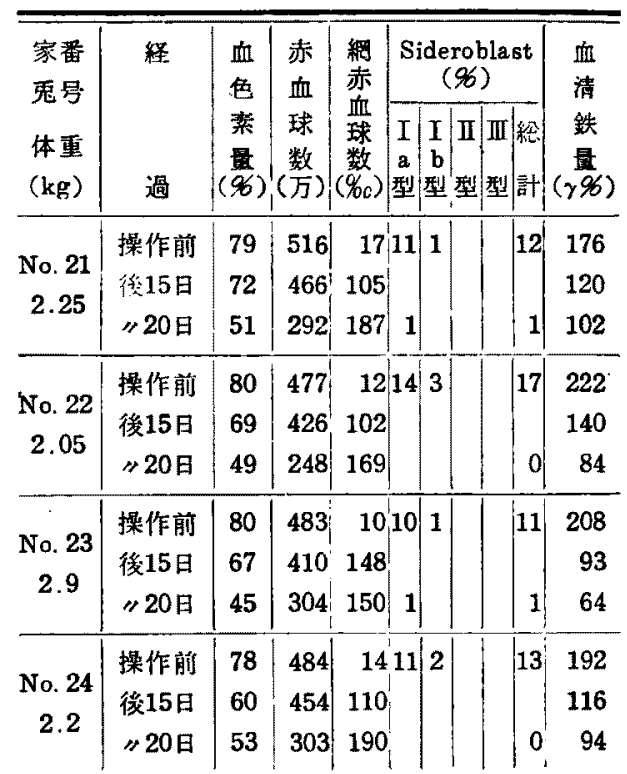

第 5 図慢性演血盆血の Sideroblast

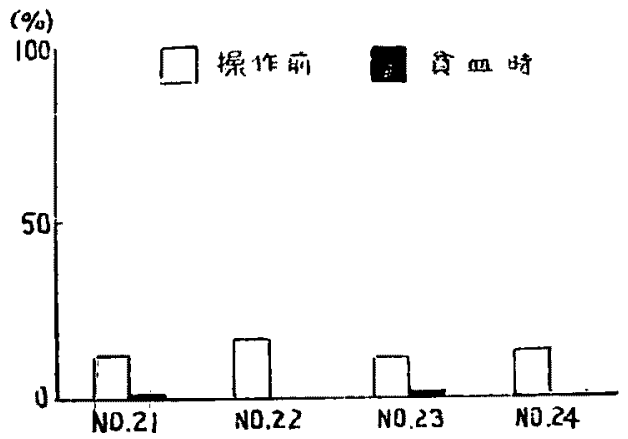

斯くの如く急性，慢性を問わず第血貧血で は Sideroblast と血清鉄の問飞平行的関係か 見受けられた。

第7節フェニールヒドラジン貧血

家鬼 (筑 7 装，第 6 因)

本畕血操作を等施した 6 例について網赤血 球分利を認める骨榷の雨生機能旺盛なる時期 飞梌索を行つた。

Sideroblast は正常状態と大差のない 7〜23 96なる俻を示し，経過的炕見れば減少 4 例， 增加 2 例であり，共に1096以下の僅かな変動 でやや減少傾向が勝るるほぼ現状維持の状態 を示した。

己飞対して血清鉄量は全例洪飞增加を認め， 
第 7 表 フェニールヒドラチン貧血

\begin{tabular}{|c|c|c|c|c|c|c|c|}
\hline \multirow{2}{*}{$\begin{array}{l}\text { 家番 } \\
\text { 鬼号 } \\
\text { 体重 } \\
\text { (kg) }\end{array}$} & \multirow{2}{*}{ 経 } & \multirow{2}{*}{$\begin{array}{l}\text { 血 } \\
\text { 色 } \\
\text { 素 } \\
\text { 量 } \\
(\%)\end{array}$} & \multirow{2}{*}{$\begin{array}{l}\text { 赤 } \\
\text { 血 } \\
\text { 球 } \\
\text { 数 } \\
\text { (方) }\end{array}$} & \multirow{2}{*}{$\begin{array}{l}\text { 網 } \\
\text { 赤 } \\
\text { 血 } \\
\text { 球 } \\
\text { 数 } \\
(\%)\end{array}$} & \multicolumn{2}{|c|}{$\begin{array}{c}\text { Sideroblast } \\
(\mathscr{6})\end{array}$} & \multirow{2}{*}{$\begin{array}{c}\text { 血 } \\
\text { 清 } \\
\text { 鉄 } \\
\text { 㟟 } \\
(\gamma \%)\end{array}$} \\
\hline & & & & & 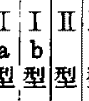 & & \\
\hline \multirow{3}{*}{\begin{tabular}{c|c} 
No. 25 \\
2.1
\end{tabular}} & 操作前 & 85 & 462 & $10 \mid 17$ & 7 & 17 & 154 \\
\hline & 後 2日 & 55 & 290 & 236 & & & 169 \\
\hline & r 5 日 & 50 & 207 & 2429 & 9. 2 & 11 & 178 \\
\hline \multirow{3}{*}{$\begin{array}{c}\text { No. } 26 \\
2.1\end{array}$} & 操作前 & 83 & 422 & 2816 & 64 & 20 & 152 \\
\hline & 後 2 日 & 52 & 214 & 388 & & & 170 \\
\hline & " 5 日 & 45 & 210 & 72012 & $2 \quad 6 \quad 3$ & 21 & 194 \\
\hline \multirow{3}{*}{$\begin{array}{c}\text { No. } 27 \\
2.3\end{array}$} & 操作前 & 82 & 494 & $14 \mid 13$ & $\begin{array}{lll}3 & 1 & 1\end{array}$ & 15 & 184 \\
\hline & 後 2 日 & 65 & 373 & 290 & & & 190 \\
\hline & " 5 日 & 53 & 281 & \begin{tabular}{|l|l|l|l|} 
& 652
\end{tabular} & $6 \mid 1$ & 7 & 230 \\
\hline \multirow{3}{*}{$\begin{array}{r}\text { No. } 28 \\
1.92\end{array}$} & 操作前 & 75 & 477 & $24: 13$ & $\begin{array}{lll}3 & 6 \\
\end{array}$ & 19 & 180 \\
\hline & 後 2 日 & 63 & 302 & 464 & & & 177 \\
\hline & य 5 日 & 60 & 307 & 376,17 & \begin{tabular}{l|l|l}
7 & 5 & 1
\end{tabular} & 23 & 198 \\
\hline \multirow{5}{*}{$\begin{array}{r}\text { No. } 29 \\
1.88\end{array}$} & 操作前 & 77 & 545 & $21: 18$ & \begin{tabular}{l|l|l|l|}
8 & 1 & 3
\end{tabular} & 22 & 160 \\
\hline & 後 2 日 & 50 & 304 & 345 & & & \\
\hline & $\approx 5$ 日 & 57 & 306 & 2288 & $\begin{array}{lll}8 & 3 & 1\end{array}$ & 12 & 277 \\
\hline & 回復 3 週 & 77 & 500 & 7 & & & \\
\hline & " 6 䓢 & 80 & 502 & $6 \cdot 33$ & $3: 14$ & 62 & 176 \\
\hline \multirow{5}{*}{$\begin{array}{r}\text { No. } 30 \\
2.42\end{array}$} & 操作徝 & 81 & 569 & 1211 & 18 & 19 & 152 \\
\hline & 後 2 日 & 42 & 270 & 360 & 11 & & \\
\hline & $\approx 5$ 日 & 56 & 287 & 172,13 & $\begin{array}{lll}3 & 4 & 1\end{array}$ & 18 & 224 \\
\hline & 回微 3 崌 & 68 & 482 & $11 \mid$ & 11 & & \\
\hline & " 6 週 & 83 & 543 & 829 & 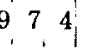 & 40 & 147 \\
\hline
\end{tabular}

第 6 図フェニールヒドラチン貧血の Sideroblast

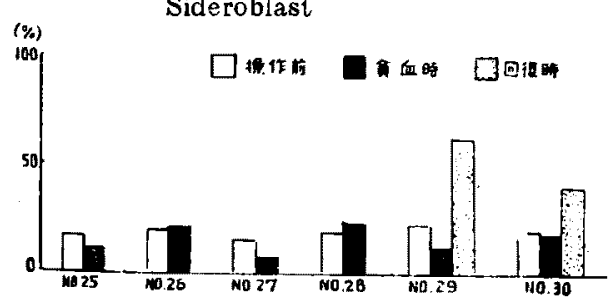

鉄顆粒の性状には殆んど変化を想めなかつた。

更に内 2 例の No. 29 及び No. 30 家宫飞於 いて圎血極期の検索後 6 週間を経過し，血液 像の完全飞正常值に復した時期《再度観繁を 行つた所, Sideroblartは 2 例共飞高度の增加 を認め，Ia，Ib，II型の增加が見られたが， III型の出現は認められなかつた。而して血消
鉄量は之に反し貧血極期の堌加から再び正常 值に復していた．鉄顆粒はこの時期に大かつ 浱染し明瞭に認められた。

更に本資血の極期と回復期とを対比した場 合K，Sideroblast と血清鉄との関係㞴度逆 の状態を示している.

第 8 節 サポニン䨘血家鬼（第 8 表， 第 7 図)

本資血操作を帮施せる5例について検索を 行い, 内 4 例に貧血極期に於ける観察を行つ た所, Sideroblast は 14 20 96 K出現し, 正 常状您と大差なく，又経造的飞子各例共 $5 \%$ 第 8 表 サポニン貧血

\begin{tabular}{|c|c|c|c|c|c|c|c|c|c|}
\hline \multirow{2}{*}{$\begin{array}{l}\text { 家番 } \\
\text { 克号 } \\
\text { 体重 } \\
(\mathrm{kg})\end{array}$} & \multirow{2}{*}{$\begin{array}{l}\text { 経 } \\
\text { 過 }\end{array}$} & \multirow{2}{*}{$\begin{array}{c}\text { 血 } \\
\text { 色 } \\
\text { 素 } \\
\text { 暴 } \\
(\%)\end{array}$} & \multirow{2}{*}{$\mid \begin{array}{l}\text { 赤 } \\
\text { 血 } \\
\text { 球 } \\
\text { 数 } \\
\text { (方) }\end{array}$} & \multirow{2}{*}{$\begin{array}{l}\text { 程 } \\
\text { 赤 } \\
\text { 血 } \\
\text { 球 } \\
\text { 数 } \\
(\%)\end{array}$} & \multicolumn{4}{|c|}{$\begin{array}{c}\text { Sideroblast } \\
(\mathscr{C})\end{array}$} & \multirow{2}{*}{$\begin{array}{c}\text { 血 } \\
\text { 清 } \\
\text { 铁 } \\
\text { 量 } \\
(\gamma \mathscr{6})\end{array}$} \\
\hline & & & & & $\begin{array}{l}\mathrm{I} \\
\mathrm{a} \\
\text { 型 }\end{array}$ & $\begin{array}{c}I \\
\mathbf{b} \\
\text { 型 }\end{array}$ & & II $\mid \begin{array}{l}\text { In } \\
\text { a }\end{array}$ & \\
\hline $\begin{array}{c}\text { No. } 31 \\
1.9\end{array}$ & $\begin{array}{l}\text { 操作猜耐 } \\
\text { 後10日 } \\
\text { 20日 }\end{array}$ & $\begin{array}{l}78 \\
65 \\
62\end{array}$ & $\begin{array}{l}459 \\
415 \\
412\end{array}$ & \begin{tabular}{r|}
12 \\
8 \\
4
\end{tabular} & $\begin{array}{l}20 \\
17\end{array}$ & 3 & & 20 & 242 \\
\hline $\begin{array}{c}\text { No. } 32 \\
2.1\end{array}$ & $\begin{array}{l}\text { 操作前 } \\
\text { 後10日 } \\
20 \text { 日 }\end{array}$ & $\begin{array}{l}80 \\
65 \\
69\end{array}$ & $\begin{array}{l}650 \\
508 \\
354\end{array}$ & $\begin{array}{r}15 \\
6 \\
9\end{array}$ & $\begin{array}{l}20 \\
17 !\end{array}$ & 2 & & 20 & $\begin{array}{l}266 \\
220 \\
150\end{array}$ \\
\hline $\begin{array}{c}\text { No. } 33 \\
1.9\end{array}$ & $\begin{array}{l}\text { 操作用 } \\
\text { 後10日 } \\
\text { "20日 }\end{array}$ & $\begin{array}{l}72 \\
67 \\
66\end{array}$ & $\begin{array}{l}500 \\
403 \\
328\end{array}$ & $\begin{array}{l}15 \\
33 \\
22\end{array}$ & $\begin{array}{l}16 \\
11\end{array}$ & 3 & & 16 & $\begin{array}{l}216 \\
200 \\
188\end{array}$ \\
\hline $\begin{array}{c}\text { No. } 34 \\
1.9\end{array}$ & $\begin{array}{l}\text { 操作前 } \\
\text { 後10日 } \\
\text { 20日 }\end{array}$ & $\begin{array}{l}82 \\
68 \\
67\end{array}$ & $\begin{array}{l}448 \\
371 \\
375\end{array}$ & $\begin{array}{l}10 \\
16 \\
10\end{array}$ & $\begin{array}{l}10 \\
10\end{array}$ & 2 & 1 & 12 & 164 \\
\hline No. 35 & $\begin{array}{l}\text { 操作萠 } \\
\text { 後10日 } \\
\approx 20 \text { 日 }\end{array}$ & $\begin{array}{l}77 \\
68 \\
62\end{array}$ & $\begin{array}{l}459 \\
406 \\
364\end{array}$ & $\begin{array}{l}23 \\
20 \\
16\end{array}$ & 14 & 2 & & 16 & 188 \\
\hline & 4日 & 73 & 530 & 4 & & & & 15 & 175 \\
\hline
\end{tabular}

第7図 サポニン筫血の Sideroblast

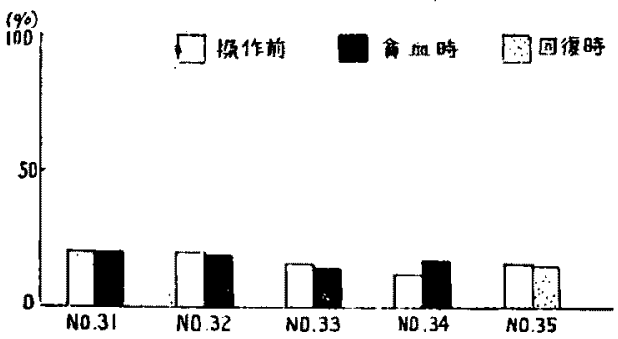


以内の変動であり著変を認めなかつた，鉄顆 粒についても同様に格別変化らしきものは観 察されなかつた，又血清鉄量佀関しては軽度 減少を全例行認めた。

更飞 1 例の No. 35 家鬼飞於いては極期後 14日間放置して血液像の回復を認めたる後検 索を行つた所, Sideroblast は之また正常状態 との間に何等差異を認め得なかつた。

\section{第 4 章 棇括並に考按}

家鬼の Sideroblast K関しては未だ何等そ の研究報告を認めない所である。私は正常家 兔及びその骨葡機能状態を種々变化せしめた 負血家鬼について既述の如く Sideroblast $の$ 検索を行い，状態变化によるその变貌を観宗 乙，而して骨髄造血機能状態が之を最も左右 する因子である事を認めた，以下個々の場合 について考察を行う事とする。

\section{1）正常家鬼}

硉康人に Sideroblast が常在する事と同様 そ，正常家鬼に於いてもその出現は比較的低 率とはいうすの全例に証明された，即ち趾 康人の下界附近より鉄欠之型の上界附近に相 当する值を示したが，この出現率の低い現象

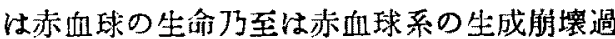
程飞附随した鉄の再利用情況の相違飞より蒸 起される可能性があり，徒つて赤芽球の成熟 過程の遅速による影響もまた大なる如く見受 けられる，而して正常家兵に悉くSideroblast を認める事奏は，硉康人の場合と相俟つてこ の赤呀球鉄が鉄の利用経路に於ける中間の代 謝物質であるという事を更に强調する現象と して興味がある。

2）ヘンンソール筫血家兔

本實血操作は Sideroblast K著明な変化を 招来し，全例飞著增を認め正常状的の数倍に す達した，之に比して血清鉄量の增加は決し て著明とはいえない有栐であつた，而して Sideroblast KはII，型の出現があり，赤第 球鉄る明かに増加を示していた，又回復期に 再び正常值に復した事は注目に值する現象で ある.
ペンソールの造血飞及任す影響飞関して は，可成り以前より白血球毒として認められ，

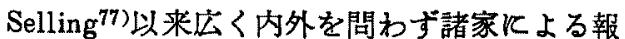
告が存在し，赤血球系住対する障碍すまた示 される所である，即ち骨䯣の荒瘦は再生不良 性貧血類似の様相を呈し，骨髄像について観 察せる森田 ${ }^{78}$ 及ひび教室上村79)飞よれば赤芽球 の減少があり，更に上村 ${ }^{79}$ 法幼若型の比較的 增加を認めている，一方本貧血の網内系機能 について教室中山影はコンゴーロート法によ り本実験と同一家鬼にその機能低下を認めて いる.

茲飞鉄代謝を中心にして本貧血を概観すれ ぼ，現在迄にその報告は極めて僅かであり， 井村 ${ }^{81}$ は本費血飞於いて荿器の退行変性之共 飞肝胋飞鉄沈着著明なるを認め, 又更飞教室 米谷，水田，中塚 ${ }^{82)}$ は本実駼と同一家鬼《於 いて䑏器含鉄星を米山，紺野83) 氏法飞従い分 劃測定し，各臟器分劃鉄量は肝では在任正常 乃至減少を，脾，骨霜では PI（Hemosiderin 分劃)，P III（核蛋白及び高分子物質飞由来す る鉄分劃）殊飞後者の著明な増加を来し，又

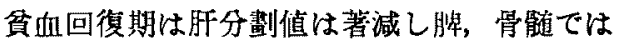
極期飞较へ軽減を示す事を述へ，本貧血時に 於故る非へミン鉄の変動を認めている，斯か る際に Sideroblast の著明な增加が認められ る事は，ヘンンソール中毒による再生不良性貧 血槏の骨髄造血障碍により赤芽球の成热段階 と平行して取行われる血色素の生成が障㥂さ れ円滑を欠ぐため鉄の利用不全を若起し，赤 芽球内に非へミン鉄の漢溜を見るすのと解さ れ，從つて再生不良性貧血に際して Moore ${ }^{399}$ ， Heilmeyer ${ }^{40)}$ の述へた如き骨䯣の鉄利用不全 飞由来する血清鉄量の增加が見られるすのと 考光られ，更飞臟器鉄量についてる同㥞であ る. 又 Sideroblast と骨䯣 PI， P III 殊K P III の増加とはその期を一にし双方の間に密接な 関係の存在が思芌される。

3）コラルゴール筫血家黖

本畕血招来時飞於ける Sideroblast の增加 は血清制量が增減不定の概ね現犾維持の值を とるにも拘わらず著明で, 就中再生不能海 
つた 1 例に於いては特に顕著であり，奏にこ の赤芽球鉄の增加は私の行つた全実験中最も 印象的であつた。

コラルゴールの静注が骨髄機能を低下せし め或は再生不能状態をる惹起する事は小宮 ${ }^{84)}$, 前田 ${ }^{85}$ ，光藤 ${ }^{86}$ 等により認められる所であり， 小宮 ${ }^{84}$ 江骨髄の萎維, 出血, 網状織内被細胞 の封鎖をその主因とし, 赤血球系に於ける造 血が極度に障碍される事はまた私の実験に於 いてる明瞭に現われている。

鉄代識を中心体負血を観察すれば，血清 鉄量に関しては Thoenes u. Aschaffenburg ${ }^{87}$ 及び三浦 ${ }^{88)}$ の報告により共に減少傾向を認め るも，三浦 ${ }^{81}$ は貧血進行の途上飞減少を認め， 負血が著明となれば减少を認めないという。 私の結果むほぼ同様の傾向を認めたが，垻血 の極期飞増加の傾向を示するのあうた．之 は長島阳のいう如く、コラルゴールの少量は 網内系機能を六進せしぬ，中等量及び大量な らば低下させる事，更飞教室中山年)により 本実駼と同一家鬼に示された負血極期の機能 低下という事等より考えれね゙，骨髄の造血障 碍以外飞全身の網内系の鉄代謝飞及ぼす影響 というすのす全経過を通じ相当関与している そ考えられる.この点再生不良性の骨髄障碍 を第一義とするヘンンソール畕血に比して，骨 喵障碍による畕血促進の下地に，常により網 内系の変動が関与しているといえる，即ち第 一編飞於いて述へた白血病中の或場合とその 機轱は同一でないにしても，現われた状怨は 可成り類似した所が見受けられる椂である.

又教室米谷，水田，中塚息恃本然䮖之同一家 東飞於いて前述の如く荟器鉄分剽測是を試み， 肝の各分劃は共僅かに隇少せるも，媳，骨 傕の PIII がやや増加の傾向を有する事を認め ている，而して Sideroblast の㩆著な增加は 骨髄造赤血球機能障得により䓗起された铁利 用不全のためと解されるが，それにる拘わら ず血清鉄量の変動が少いのは，根底に網内系 の異常が存在しているためという事が出来, 又この他出血による影響す関与している可能 性がある，更に本盆血洔に Sideroblast の增
加と共に骨髄のPの增加が認められる事は, 前述のベンゾール筫血の場合と其に甚だ興味 深い結果である。

4）レントゲン貫血家鬼

本貧血を招来せしめた場合，血清鉄量は極 期にやや诚少傾向が認められるが, Sideroblast は前述のヘンソソール，コラルゴール両 貧血の場合程著明ではないにしても全例にそ の增加を認め得た。

レントゲン楾の造血に及ぼす影響に関して は, 今世紀の当初 Heineke ${ }^{90)}$, Milchner $u$.

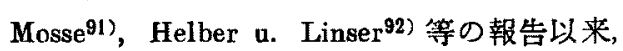
その研究は広く内外を問わず実に多彩を極め, その業績は枚挙に遑がない，然しながら之等 を一括思考する時，造血に及ぼす影響として 赤, 白両血球系共傽碍されるが，赤血球系 は比較的抵抗性大であり，その障碍にはやや 大量の照射を要する事が諸家のほぼ致した 意見である、この点私の塞験る大体同様の結 果を辿り，中等度の貧血を招来せしめる事が

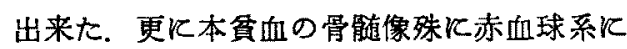
関して西川(93)，中尾 ${ }^{94)}$ 等は 1 回大量照射飞 より幼若型が先ず侵されると述へ，又教室上 村 ${ }^{79)}$ 《上れば中等量を頻回照射した場合，幼 若型よりの成然抑制が考えられるという，絧 内系機能に関しては後藤 ${ }^{95)}$ とり抵抗力大な るも多少阻碍されるといわれ，又教室中山年) も本実験と同一家婜飞於いてその機能低下を 認めている.

鉄代謝を取报つた研究報告もまた散見され る所である。即ち Hoff ${ }^{96}$ 及び Chanutin ${ }^{97)}$ 白鼠老用い㫮的後血浆或は血消鉄量の增加を

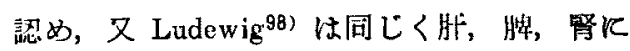
於ける貯蔵鉄の增加を示しており，更に教室 米谷，水田，中埭 ${ }^{82)}$ は本策験と同一家鬼に於 いて前述世る如く喊器鉄の伤测测定を行い， 肝, 腜, 学随の PII（Ferritin 分劃）の減少 並に殊に脾，骨能に於けるPIIIの増加を認め ている。一方 Hennessy ${ }^{99)}$ は白鼠に於いて照 射後放射性鉄 $\mathrm{Fe} \mathrm{e}^{69}$ を静脈内投与し，赤血球 中への出現を梌し血色菜への利用状態を観察 したが，極く少最の照射に於いて既に利用の 
低下を認め，増量するに及び障碍の顕著なる 事を述へている，又之等と別化 Salomon 及 び Richmond は 2-C-14 glycine を用いて血 色素合成過程の照射による影響につき種々検 討を重ねている(100). 斯かる際に於ける Sideroblastの增加は，骨髄造赤血球譏能障碍によ り Hennessy ${ }^{99)}$ の認めた如き鉄の利用不全に よる事は疑 5 余地のない事であり，従つて骨 䯣の赤血球系飞利用され得へき非へミン鉄の 貯溜が見られると考えられる。

\section{5）演血貧血家鬼}

本筫血を招来せしぬた場合 Sideroblast は 著明に減少し，殊に頻回滨血を実施した慢住 型の場合には激減を示し，消失を認めた例も あつた．本貧血の造血状感に関しては之迄に 多数の研究がなされ，Blumenthal ${ }^{101) ， L i n-~}$

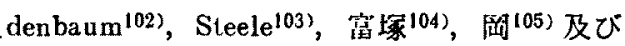
教室上村79)等《より組織学的或は骨髄像に於 ける検索が行われ，而して何れる造赤血球機 能の六進を琹め，赤芽球殊にその成熟型の增 加を認めている，網内系機能については教室 中山 ${ }^{80}$ とより本実験と同一家鬼に於いてその 機能立進が示されて招り，浮田106) の報告に 一致した結果を認めている。

本畕血の鉄代謝に於ける変動は著しく，諸 家により难々実験対象として用いられる所で あるが，血清鉄量に関しては諸種の動物が策 䮖に供され，又私の成續も示与如くその減少 は Fontés et Thivolle ${ }^{57)}$, Warbur'g u. Krebs ${ }^{38)}$, Thoenes $u$. Aschaffenburg ${ }^{87)}$, Locke ${ }^{(07)}$, 河

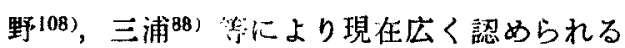
所である。この際先ず挙げられる原因として Fontés et Thivolle ${ }^{57)}$ 及び Heilmeyer ${ }^{40)} の い$ 万前述の骨髄造血機能元進による鉄消費の增 加が最も考えられる所であるが，他に Heilmeyer ${ }^{40 /}$ は失血に上る鉄欠之, 組織液流入に よる鉄濃度の稀秋及び血球朋垻の减少等を挙 げている，而して造血機能元進による鉄消費 の增加は急性汻血贫血の, 又失血による鉄欠 之は慢性渞血貧血の最有力因子となり得る事 が考えられる，更に臟器鉄䝿に関しては Fon-

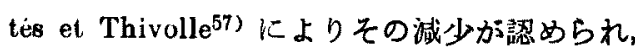

又山下 109)の詳細な報告があり，而して教空

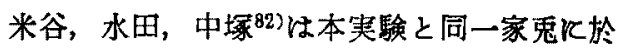
いて前述の分劃測定を行い, 肝, 腗, 骨淢の 各分劃共飞一様に減少を認め，肝の減少著明 で殊にPII の減少著しくPI 動員利用され る事を述へている，本貧血に於ける Sideroblast の減少は急性演血では旺盛なる造血機 能に伴つて赤芽球の增生著しく, 同時に血色 素生成による鉄利用が元進するために惹起さ れた現象て，鉄の利用が血清中よりの補給に 優るためと考えられ，又その減少の比較的軽 度な事は供給源としての歲器鉄の減少が高度 でないためと解される，而して慢性瀉血では 私の実験でな拓造血機能の元進を認めてはい， るものの，高度の減少乃至消失を示した事は， 頻回淊血による臟器鉄の著しい減少により造 血に対する鉄供給の不足を来す事が更により 重要な役割をなするのと思考される。

6）フェニールヒドラジン分血家鬼

朴曾血に於いて Sideroblast は極期㳊著变 を認めなかつたが，回復期には著しい增加を 示した。而してえと反对に血清鉄量は極期に 增加し，回復期には平常に復した。

フュニールヒドラシンが強力な赤血球破壊 作用を有し，従つて本貧血が溶血飞基くも のである事は周知のことで, Morawitz ${ }^{110)}$,

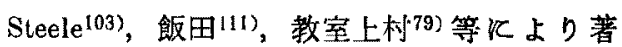
明な畕血と共飞殴盛なる骨髄雨生機能の認め られる所である。而してての骨髄像に関して はSteele ${ }^{(03)}$ 及び上朴 ${ }^{79}$ は赤芽球珠に正赤芽 球の增加を認めている，又網内系関聯して 井村 ${ }^{811}$ ，飯田(11)，龍治123等の報告が認めら れるが教室中山1 ${ }^{801}$ は本尖験と同一家鬼に於い てその機能を検し，骨骮機能の亢進にも拘わ らず軽度ながら障碍像を認め，溶血による赤 血球崩塖栍物の網内系に於ける会喰の結果と した.

鉄代謝は溶血及び之に伴 弓赤血球系の変化 㳊徒つて著明な変動を見せ，血清鉄量飞関し ては既K Heilmeyer(0), 河野113), 三浦88) K よりその增加が認められている。而して一般 に之は溶血による增加，及び骨䯣に於ける鉄 
消費の增大による減少という二大因子の左右 する所と考光られ，従つて経過的飞見て，検 する時期により翼る事は明白である。この点 K関し三浦 ${ }^{88}$ は增加後造血機能旺盛なる時期 に隇少する事を認めている。

臓器鉄飞関して井村811はその增加を認め,

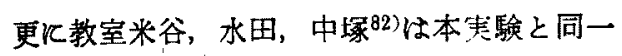
家鬼を用いて前逄の如く分劃測定を行い，肝， 骨䯣でやや增加し, 脾の $\mathrm{P}_{\mathrm{I}}$ の増加傾问及 び骨䯣の PIIIの增加を認め, 又回復期飞は極 期飞比して減少を認めている，本貧血の Sideroblast が極期に著変を示さなかつた事は, 溶血による血清鉄量の增加と同時飞骨㵦に於 ける造血機能の元進があり，従つて鉄の供給 の増加と消費の增加とが共存するために斯か る様相を呈するすのと考えられ，而してこの 事は溶血が生体に於ける鉄の損耗を来す事な く，血色素の再利用といら一環せる代謝機满 を本質的には扰大したものに過ぎないという 事からる理解され得る所である. 即ち溶血飞 より必要以上に供給される状態にある鉄を十 分に消費するために，赤芽球に於ける非へミ ン鉄としての貯溜の增加なく，両者が正常状 態の如き平衡関係にあつたためと解される。 又回復期に於ける增加は之迄旺盛であつた造 血機能の減退によると考元られ，而も瀉血時 と異りな招必要以上の供給鉄量が存在するた めと解される．以上より赤牙球鉄が血色紊分 解起因するという事は到底考光難い所であ る. 又骨喵の鉄移動の盛んな極期に骨䪔 PIII の増加が米谷等 ${ }^{82}$ によつて認められた事は注 目飞值する。

7）サポニン公血家兔

本蚠血飞於いては血清鉄量は軽度の減少を 認めたが, Sideroblastは極期並に回復期飞著 変を示さなかつた.

元来サポニンは話験管内溶血を惹起する事 より，その苗血嵱血に基くるのとされ，溶 血毒として広く認められる所であるが，ここ

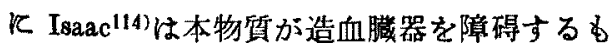
のであるとなし，又尾曾越115)によればサポ ニン衝慗により肺, 肝, 舫に未熟赤白骨骮球
の多数出現を認め, 血球の崩壊と相俟つて骨 䯣は空虚となり，而して肝，脾は骨餚の様相 を带びる様になると述へ，骨髄からの放出に よる骨髄外造血を認めている。斯くの如くサ ポニンの作用の本態は実飞複雑を極めて括り， 骨䯣像について教室上村 ${ }^{79}$ は赤芽球各階梯の 百分率には著変がないが，実数化於いて幼若 並に成熟細胞共飞一様に減少し, 赤血球の低 形成が考えられるという。

鉄の代謝飞関聯して教室米谷、水田，中 塚 ${ }^{82}$ は本実験と同一家鬼に於いて前述の如く 搭器鉄分劃測定を試み，肝，熷，骨娟の $\mathrm{P}$ II の減少傾向及び脾，骨䯣のP III の增加を認め， 前述の骨髄障碍時に類似した結果を得ている. 斯かる際 Sideroblast 飞全経過を通じて著変 の認められなかつた事は，本貧血が著明なる 経過を辿らなかつた故るあり，軽度の造血障 碍乃至は骨鹃有の変動及び溶血等の諸因子によ る錯棕せる結果と解され，又同時飞網内系の 態度る重要視さるべきであり，之等の詳細は 貧血の発生機転の解明と洪に今後に残された 課題である。

8）全節の総括並に考按

以上ベンゾール，コラルゴール，レントゲ ン貧血の如き骨髄の造赤血球機能を障碍した 場合，血清鉄量には著明といえる程の変化を 認めないにる拘わらず, Side roblast の著しい 増加を示した事は，鉄の利用過程に関聯して この Sideroblast 乃至は赤芽球鉄の重要性を 深く考えせしめる所であり，骨髄の鉄利用状 態を察知する上に血清鉄に優る惫義を有し， 而して再生不良性寊血，白血病，放射線障碍 症飞於ける增加と共江骨酭造赤血球機能と Sideroblast との密接な関聯性を如策に示する のである. 更に之は反対の立場である滔血に よる骨髉の造赤血球譏能立進時飞 Sideroblast の減少を認めるという事実により確認される 所であり，従つて赤莪球鉄が血色素飞利用さ れる運命にある事は疑う余地のない事である. 又鴧血に際しては二次的に惹起された鉄欠之 状態む一役を演ずる様になる事は鉄欠之性盆 血の総てK見出される減少傾向と一致して重 
要なる因子であり，更に溶血による鉄供給の 過剩とい5事子鉄欠乏性䝯血飞於ける鉄剂投 与時の增加と共飞 Sideroblast を左右する因 子となり得る訳である。即ち骨髄造赤血球機 能状態の影響以外飞上る血清鉄量の変動が之 である.

Kaplan ${ }^{32)}$ は Sideroblast と血清鉄量との間 そ関聯性を認めたが，この両者は本態的には 密接な関聯を有しているものの，実際に表現 された状態では可成り暴つた漛相を呈してお り，私の成䋶が之を明腺に示している，即ち 両者は何れも鉄の血色素への利用という代謝 過程に存在し，而して Sideroblast は造赤血球 機能状態により左右され，又血清鉄量にも影 㸷されるが，之K対し血清鉄量は Sideroblast を介しての造赤血球機能状態に左右される 事の外，網内系の状態を始め晹管吸收の状 態，出血飞よる铁損耗の状態筞飞影響され易 い事によると解される. 而も造尗血球機能障 碍時に於いて殊飞顕著である斯かる雨者間の 相淕は，この赤茅球鉄が尃ら利用火のみ方向 付けられている事を示するのとして興味深い.

斯くの如く Sideroblast は骨髓機能と最も 関係深い訳であるが，その変動の本態は骨骮道 造赤血球機能飞よる鉄の利用状態と血清鉄飞 よる供給状悲の間に存在する平衡関係如何に あり，而しで同じ造赤血球機能の亢進でる瀉 血の場合には減少するが，フェニールヒドラ シンによる溶血の場合には不変である事は, この関係を良く示している，以上は飽くまで 概観的な Sideroblast の消長関してである が，更に個々の赤牙球について赤牙球鉄の観 察を行つた場合は，前編に述へた如き発育段 階等に応じた收容能力の問題があり，従つて 赤牙球の鉄摄取とい5問題になると可成り複 雑で，赤芽球内部の状態が関与する事け明白 である．即ち赤芽球内に於ける血色淁及び非 ヘミン鉄の状態如何が関係するという可能性 が十分考えられ，Granick ${ }^{75) 76)}$ の. mucosal block なる腸管吸收機棈の仮説に類似して此 処でも摄取の制約が想定される。

又 Granick ${ }^{116)}$ は眝荿鉄飞関して以下の 3
つの部分に之を分類した。

1. monomolecularly dispersed iron compounds

2. colloidal iron compounds (Ferritin and non-crystallizable Ferritin)

3. microscopically visible granular iron material (Hemosiderin)

而して最近諸家により之等の眝藏鉄を分割 測定する試みがなされて括り，前述せる如く 教室米谷，水田，中塚 ${ }^{82}$ は本実験々同一家鬼 を用いて米山，緗野833 氏法による分劃測定を

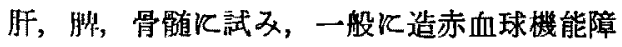
碍飞際して P而（核蛋白及び高分子物質飞由 来する鉄分劃) の増加を骨蹥，脾に認めた。

之は Sideroblast 乃至赤芽球鉄の增加と一致 した所見である. 又フェニールヒドラシン筫 向に際しても同㥞に P III の増加を骨髄に認め, この際 Sideroblast の出現率は不変であるが, 赤芽球の增生があり，利用される鉄は大量保 移動していると見做される。然しながらその 他 PI (Hemosiderin 分劃), PII (Ferritin 分 劃）と Sideroblast との関聯は認められず, 従つて赤第球鉄と Hemosiderin との関聯性は Rath \& Finch ${ }^{55)}$, Davidson ${ }^{66)}$, Hutchison ${ }^{47)}$ 等の骨髄標本との相遱からる明か飞示される 如く先ず考光難い所であり，又 Ferritin との 相湋は諸点よりして更に明瞭である。而して Sideroblast 乃至赤芽球鉄と PII と何等かの 関絗を有するるのであり，又この際血清鉄る 多少共両者飞同調する如く見受けられる，斯 かる事実より赤第球鉄，PIII，血清鉄の間飞 興味深い関聯が考方られ，特浾第球鉄と骨 髄 PIII の間は密接であり，骨髄 PIII の内飞赤 芽球鉄が含まれるという可能性る十分考克ら れる，而る之等は広義の貯蔵鉄の中で共に利 用火際して最子動き易い鉄と解され，事実 PIII が PI， PII K比して利用され易い傾向K ある事は，塩見及(゙著者 ${ }^{117)}$ の放射性鉄 $\mathrm{Fe}^{65}$ を用いた実験で認める所であり，又斯かる 利用され易い鉄飞関して既に Greenberg \& Wintrobe ${ }^{4)}$ 怔投与された放射性鉄の利用度と 1 日の赤血球崩壊飞よる鉄量とから貯蔵鉄の 
中特に利用され易い labile iron pool の存在 を考えてょり，この様な鉄のるつ重要性を示 している.

\section{第 5 章 結}

\section{論}

1）家秃35例飞つき主として骨髄造血機能 を中心諸種の実験的貧血を惹起せしぬ，経 過的水 Sideroblast の推移を観祭し，血清鉄 とも対比した.

2）家鬼の正常状態に於ける出現率は健康 人に比し低調であり，又出現の範缃も狭小で あつた.

3） ヘンソール，コラルゴール，レントゲ ン貧血等の造赤血球機能低下状息に於いては 增加し，又ヘンゾール負血回復時には正常值 に復した。

4）急性及び慢性渲向貧血の造赤血球機能 元進状態並に鉄欠乏状態に於いては減少乃至 消失した。
5）フェニールヒドラシン筫血の如き溶血 状態に於いては時期的に異り，極期に著変な く回復期に增加した，又サポニン貧血では著 変を認めなかつた。

6）Sideroblast と血清鉄の間にはさして明 瞭な平行関係を認めるとは限らないが, 共に 利用に詨し䡃き易い立場にあり，更にこの赤 芽球铁は利用にのみ方向付けられた，最る利 用され易い鉄と解される。

7）以上より Sideroblast 乃至赤苛球鉄の 変動は血清鉄による鉄の供給と造血機能によ り左右される鉄の利用との間に存在する平衡 状態の如何に依存するすのである.

稿を䅂るに臨み釉始御想第なる御指導と御校閱を 賜わりたる恩唔平木教授に深甚の謝意を表すると共 飞大藤助敉授の御校閲並飞米谷博士の御援助を深謝 する.

（文献は巻尾に一括記载する）

\title{
Studies on Sideroblasts
}

\section{Part 2}

\section{Sideroblasts and Bone Marrow Functions (Experimental Anemias)}

\author{
By \\ Ikuro Kimura \\ Department of Internal Medicine, Okayama University Medical School \\ (Director: Prof. Kiyoshi Hiraki)
}

Various experimental anemias have been induced in adult rabbits mainly centering around the hematopoietic functions of the bone marrow; and with continuous observations on the changes of sideroblasts, a series of comparative studies between the sideroblasts and serum iron has been carried out; and obtained the follwing results :

1) The proportion of sideroblasts in normal rabbits is lower and the extent of the sideroblast appearance less extensive than that in the normal persons.

2) The proportion of sideroblasts increases in such anemias where there is a decline in the erythropoietic function as in benzol, collargol, x-irradiation anemia, whereas it returns to normal level at the time when the benzol anemia is recovering.

3) The proportion of sideroblasts either decreases or becomes nil in acute and chronic hemorrhagic anemias where there exist an increase in the erythropoietic function and iron 
deficiency.

4) In the case which is in the process of hemolysis such as in the phenylhydrazine anemia, the proportion varies according to the period; and it shows no marked change at the extreme periods while it increases at the time of recovery. Furthermore, no significant change can be observed in the saponin anemia.

5) Parallel relationship between sideroblasts and serum iron is not always clearly noticeable, but the two seem to be always in the state labile to utilization. Again, this stainable iron in erythroblasts is understood to be directed solely for utilization and is by far the most labile to iron utilization.

6) From these observations, it may be said that the changes of sideroblasts or of this stainable iron, are dependent upon the conditions of equilibrium existing between the iron supply by serum iron and the utilization of iron controlled by hematopoietic functions. 